\title{
Improvement in the manufacturing process and quality of jujube vinegar in the ancient literature "Sangayorok』
}

\author{
Hyeon-Ju Park, Seong Hyun Jeon, So-Young Kim, Soo-Hwan Yeo, Hee-Min Gwon* \\ Fermented Processing Food Science Division, Department of Agrofood Resource, NIAS, RDA, Wanju 55365, Korea
}

\section{박현주 · 전성현 · 김소영 · 여수환 · 권희민* \\ 농촌진흥청 국립농업과학원 농식품자원부 발효가공식품과}

고문헌 『산가요록』에 수록된 대추식초의 공정 개선과 품질 특성

\begin{abstract}
Jujube vinegar is produced using a method described in the ancient literature titled "Sangayorok". In this vinegar production method, alcohol and acetic acid fermentation occur at the same time. This study was conducted to reproduce the traditional jujube vinegar and improve its quality. The manufacturing proess was divided into two stages of fermentation. Jujube wine was prepared using the base liquor (Mit-sool), and jujube vinegar was prepared by seed vinegar. Moreover, the optimum conditions were determined by analyzing the quality of the fermented jujube vinegar at different temperatures $\left(20,30\right.$, and $\left.35^{\circ} \mathrm{C}\right)$ and initial $\mathrm{pH}$ conditions ( $\mathrm{pH} \mathrm{3,4}$, and 5). We evaluated the $\mathrm{pH}$, acidity, organic acid content, and antioxidant activity of the fermented jujube vinegar, and its taste was analyzed using an electronic tongue. On the $14^{\text {th }}$ day of fermentation under $\mathrm{pH} 4$ and at $20^{\circ} \mathrm{C}$, the $\mathrm{pH}$ level dropped to 3.4 , and the acidity was $10.4 \%$. The total organic acid content was $6,568 \mathrm{mg} / 100 \mathrm{~mL}$, of which acetic acid content was as high as $83 \%(5,475 \mathrm{mg} / 100 \mathrm{~mL})$. Umami and sourness of the vinegar increased as the fermentation progressed. Analysis of antioxidant activity of the vinegar fermented at $\mathrm{pH} 4$ and $20^{\circ} \mathrm{C}$ revealed that the ABTS radical scavenging activity of the jujube vinegar was $90.9 \%$, and the total polyphenol content was $1,131.3 \mathrm{mg}$ (GAE)/100 mL. These findings can form a basis for selecting optimal fermentation conditions and developing manufacturing technologies through modemized process improvements for commercialization of traditional jujube vinegar.
\end{abstract}

Key words : Acotobacter oryzifermentans, ancient literature, fermentation, jujube vinegar, Sangayorok

\begin{abstract}
서 론
식초는 동서양을 막론하고 술과 함께 인류의 식생활에서 가장 오래된 식품 중 하나로 당류, 휘발성 및 비휘발성 유기 산, 아미노산, 에스터 등이 풍부하며, 신맛을 지닌 대표적인 발효식품이다(Jeoung과 Lee, 2000). 우리나라에서도 예로부 터 식초를 음식의 조미료로 사용한 기록들을 볼 수 있다. 식 초 제조법이 수록된 고문헌 중 가장 오래된 『산가요록』은
\end{abstract}

1459 년경 조선 전기 의관인 '전순의'가 집필한 조리서이다 (Lim과 Cha, 2010). 『산가요록』은 우리나라 사람에 의해 기 술되었으며, 우리 풍토를 중심으로 엮어 실용적인 면에서 높 은 평가를 받고 있다. 그뿐만 아니라, 식품 부분에서는 180 여 개의 항목으로 내용이 다양하고 풍부하며, 당시 가장 수준 높 은 조리기술을 담고 있는 서적이다(RDA, 2004). 식초는 예 로부터 음식의 맛과 향미를 더해주는 조미료의 기능과 옹종 (擁腪)을 없애고 혈운(血暈)을 부수며 어육과 채소 등의 독을

*Corresponding author. E-mail : vitamin89@korea.kr, Phone : +82-63-238-3611, Fax : +82-63-238-3843

Received 12 October 2020; Revised 10 December 2020; Accepted 17 December 2020.

Copyright (c) The Korean Society of Food Preservation.

This is an Open Access article distributed under the terms of the Creative Commons Attribution Non-Commercial License (http://creativecommons.org/licenses/by-nc/4.0) which permits unrestricted non-commercial use, distribution, and reproduction in any medium, provided the original work is properly cited. 
다스린다고 하였다(Kim 등, 2013). 이 중 전자손초(傳子孫酶) 는 '자손에게 전하는 초'라는 뜻으로 대추를 이용하여 제조 한 식초이며, 자양, 강장에 효력이 있어(Kim 등, 2013) 기능 성 식초를 제조하여 식용한 조상의 지혜를 엿볼 수 있다.

대추는 전통적으로 생강, 오미자와 함께 식품과 한방재료 로 사용되었으며(Hong 등, 2010), 우리의 식생활에 오래전부 터 널리 이용되어 온 과실이다(Choi, 1990). 대추는 민간요법 과 한의학에서 '건조', '미조', '대조', '홍조', '산조'로 불리 며, 불안, 위경련, 심장쇠약, 순환계질환, 간경화, 만성기관지 염, 이뇨제 등의 약리효과(Choi, 1990; Kim 등, 2011; Yu 등, 2006)와 최근에는 대추의 항산화, 항염증, 항당뇨 등의 효과 로 기능성 소재에 관한 연구가 보고되고 있다(Hong 등, 2019; Park 등, 2017).

서구문화 영향으로 고지방식 섭취가 증가함에 따라 고혈 압, 고지혈증, 위암, 만성 위궤양, 대장암, 변비 등으로 한국인 들의 건강에 적신호가 나타나고 있으며, 건강에 대한 관심이 기능성 식품의 소비로 이어지고 있다(Kang 등, 2020). 이에 발맞춰 음료용 식초는 체지방 감소, 피로 회복, 성인병 예방 에 도움이 되는 건강기능성 식품으로 각광을 받고 있다(Cho 등, 2017; Kwon 등, 2000; Won 등, 2020).

이에 본 연구에서는 조상의 지혜가 담긴 고문헌 『산가요 록』에 기록된 '전자손초'를 재현하고, 현대적 공정 개선을 통 해 고품질 발효식초 개발과 품질 특성을 구명하고자 한다. 더 나아가 발효식초의 품질 경쟁력을 확보하고, 농산업체의 소 득 증진에 기여하고자 한다.

\section{재료 및 방법}

\section{고문헌 대추식초 재현}

고문헌에 기록된 제조법을 조사하여 원방대로 재현하고자 하였다. '전자손초'를 재현한 대추식초의 제조 과정은 Fig. 1 과 같다. '전자손초' 재현을 위해 반만 익은 대추를 식초 제조 에 사용하였다. 원방에서 사용한 단위는 '말', ‘동이'이며, 이 두 단어는 같은 용량으로(RDA, 2011) 항아리에 시료인 대추

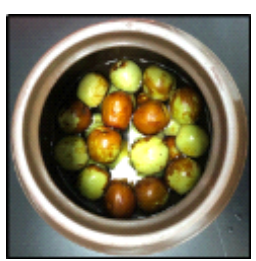

Jujube $1 \mathrm{~kg}$ + water $1 \mathrm{~L}$

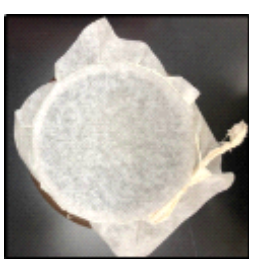

Fermentation

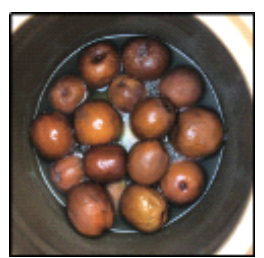

Jujube vinegar
Fig. 1. Reproducing the manufacturing process of 'Jeonjashoncho' in ancient literature.
와 물을 동량으로 담아 대추식초를 제조하였다. 상온(약 $\left.25^{\circ} \mathrm{C}\right)$ 에서 정치 상태로 자연 발효하였고, 21일간 7일 간격으로 샘 플링하여 분석에 사용하였다.

\section{사용 원료}

본 실험에서 사용된 대추는 김제 농협에서 구매하여 사용 하였다. Kim 등(1994)은 대추 추출 농축액의 수율은 씨를 제 거한 경우가 제거하지 않은 경우보다 2-3배 증가하였다고 하 였고, Kwon 등(1997)은 씨를 제거한 건조대추가 일반 건조 대추보다 추출 시간이 5 배 단축되고, 당도가 더 높았다고 하 였다. 이에 대추 추출 농축액의 수율을 증가시키기 위해 대추 씨를 전부 제거한 후, 대추 양에 대해 10 배 가수한 뒤 $80^{\circ} \mathrm{C}$ 에 서 8 시간 열수 추출하고, $20^{\circ} \mathrm{Brix}$ 가 되도록 농축하여 실험에 사용하였다.

\section{시판 식초}

시판 식초는 (주들산초의 대추 담은 발효식초(A)와 발효촌 의 대추 발효초(B)를 온라인으로 구매하여 사용하였다. $\mathrm{A}$ 제 품의 원료 함량은 대추추출액 $83 \%$ (대추열매 $9.09 \%$, 정제수 $90.1 \%$ ), 유기현미 $16 \%$, 엿기름 $1 \%$ 이고, B 제품은 대추농축 액 $30 \%\left(10{ }^{\circ} \mathrm{Brix}\right)$, 정제수, 이소말토올리고당, 고과당, 사과농 축액, 구연산, 비타민 $\mathrm{C}$, 벌꿀, 효소처리스테비아 등이 첨가되 어 있는 제품을 항산화활성 실험의 대조구로 사용하였다.

\section{주모 제조 및 대추주 제조}

국립농업과학원 발효가공식품과 발효자원연구실에 보존 중인 효모 중 알코올 발효능이 우수한 균주인 YM22(Saccharomyces cerevisiae, $\mathrm{KACC}$ 48337)를 이용하여 주모를 제작 하였다. YPD broth $5 \mathrm{~mL}$ 에 $0.1 \%(\mathrm{v} / \mathrm{v})$ 접종하여 $25^{\circ} \mathrm{C}, 48$ 시 간 배양한 주모를 대추 농축액의 $0.1 \%(\mathrm{v} / \mathrm{v})$ 접종하고, $25^{\circ} \mathrm{C}$ 에서 14 일간 정치 발효하여 대추주를 제조하였다.

\section{종초 제조 및 대추식초 제조}

국립농업과학원 발효가공식품과 발효자원연구실에 보관 및 기탁 중인 초산균 중 산 생성능이 우수한 균주인 Acetobacter oryzifermentans(KACC 19301)를 이용하여 종초를 제 작하고, 대추식초 제조에 사용하였다. 초산균을 액체배지 (yeast extract $0.5 \%$, glucose $0.5 \%$, glycerin $1 \%, \mathrm{MgSO}_{4}$ $7 \mathrm{H}_{2} \mathrm{O} \quad 0.02 \%$, EtOH $6 \%$, acetic acid $1 \%$ )에 전배양한 후 $10 \%(\mathrm{v} / \mathrm{v})$ 접종하여 총산도가 $3-3.5 \%$ 가 될 때까지 정치 배양 하였다.

총산도가 3-3.5\%에 도달한 종초를 대추주(Alc. $8 \%$ )에 $10 \%(\mathrm{v} / \mathrm{v})$ 접종하였다. 이 때, 초산발효를 위한 적합 $\mathrm{pH}$ 를 알 아보기 위해 식용 구연산(Jungbunzaluer, Austria)을 이용하 
여 대추주의 초기 $\mathrm{pH}$ 를 $3,4,5$ 로 처리하고, 미리 준비한 종 초를 접종한 뒤 항온기에서 발효하였다. 적합 발효온도 선발 을 위해 발효 온도는 $20^{\circ} \mathrm{C}, 30^{\circ} \mathrm{C}, 35^{\circ} \mathrm{C}$ 로 처리하고, 발효 기간 별 $(0,6,9,14,21$ 일)로 샘플링하여 품질 특성을 분석하였다.

\section{$\mathrm{pH}$ 및 총산도 측정}

$\mathrm{pH}$ 는 시료 $20 \mathrm{~mL}$ 를 취하여 $\mathrm{pH}$ meter(Orion $3 \mathrm{star}$, Thermo scientific Co., Waltham, MA, USA)로 실온에서 측정하였다. 총산도는 10 배 희석한 시료 $1 \mathrm{~mL}$ 에 $1 \%$ phenolphthalein solution을 2-3 방울 첨가한 후 $0.1 \mathrm{~N} \mathrm{NaOH}$ 용액으로 중화 적정한 후, 소비된 용액의 양을 초산으로 환산하여 \%로 표시 하였다.

$$
\begin{aligned}
\text { 산도 }(\text { 초산, } \%)= & \text { 수산화나트륨 적정량 } \times 0.006 \text { (환산계수 }) \\
& / 10 \mathrm{~mL}(\text { 시료량 }) \times 100
\end{aligned}
$$

\section{알코올 함량 측정}

시료 $100 \mathrm{~mL}$ 와 증류수 $100 \mathrm{~mL}$ 를 시험관에 넣고 소포제 를 2-3방울 떨어뜨린 후, 증류기(VAP200, Gerhardt, Konigswinter, Germany)로 증류한 액 $80 \mathrm{~mL}$ 에 증류수로 $100 \mathrm{~mL}$ 정용하고, 밀도측정기(AT/DMA5000M, Anton paar, USA) 를 사용하여 측정하였다.

\section{유기산 함량 측정}

시료 $10 \mathrm{~mL}$ 를 취한 후 membrane filter $(0.2 \mu \mathrm{m})$ 로 여과하 여 분석에 사용하였다. 분석기기는 HPLC(LC-20A, Shimadzu Co., Kyoto, Japan)를 이용하여 post column 방법으로 분석 하였다. 유기산 분석용 칼럼은 TSKgel ODS-100V $5 \mu \mathrm{m}(4.6$ $\mathrm{mmI} . \mathrm{D} \times 250 \mathrm{~mm}$ )를 사용하였다. 이동상은 $8 \mathrm{mM}$ perchloric acid(Sigma Chemical Co., St. Louis, MO, USA)을 이용하였 으며, 유속은 $1.0 \mathrm{~mL} / \mathrm{min}$, 칼럼오븐은 $40^{\circ} \mathrm{C}$ 로 하였다. 분리 물은 반응용액 $0.2 \mathrm{mM}$ bromothymol blue(Sigma Chemical Co.), $15 \mathrm{mM} \mathrm{Na}_{2} \mathrm{HPO}_{4}$ (Sigma Chemical Co.), $7 \mathrm{mM} \mathrm{NaOH}$ 로 반응한 후 UV $440 \mathrm{~nm}$ 에서 검출하였다. 이때 반응용액의 유속은 $1.0 \mathrm{~mL} / \mathrm{min}$, 반응온도는 $25^{\circ} \mathrm{C}$ 로 하였다.

\section{전자혀를 이용한 맛성분 분석}

전자혀를 이용한 맛성분 분석은 $\mathrm{Kim}$ 등(2016)의 실험 방 법을 일부 변형하여 Alpha MOS사의 전자혀 시스템(Astree $\mathrm{V}$, Alpha MOS, Toulouse, France)을 사용하여 측정하였다. 시료는 membrane filter $(0.45 \mu \mathrm{m})$ 로 여과하여 분석에 사용하 였고, 전처리를 거친 시료 $1 \mathrm{~mL}$ 를 100 배 희석하여 비이커에 담아 오토샘플러(autosampler)를 이용하여 분석했다. 7가지 센서 중 $\mathrm{SCS}(0825-06-225)$ 와 $\mathrm{CPS}(12564-02-593)$ 센서를 standard로 사용하였고, $\mathrm{AHS}$ (신맛, 8025-05-676), NMS(감
칠맛, 12564-01-036), $\mathrm{CTS}$ (짠맛, 12564-01-005), $\mathrm{PKS}$ (단맛, 12564-02-495), ANS(쓴맛, 12564-02-563) 센서를 사용하였 다. 0-10의 범위에서 나타내었다. 5 회 반복하여 실험하였으 며, 각각의 시료 분석 후 센서 세척(cleaning)과정으로 오염을 방지하였다.

\section{ABTS radical 소거 활성 측정}

2,2'-Azino-bis(3-ethylbenzothiazoline-6-sulfonic acid)(ABTS) radical 소거활성은 $\mathrm{Re}$ 등(1999)의 방법을 응용하여 $7.4 \mathrm{mM}$ ABTS(Sigma-Aldrich Co.)와 $2.6 \mathrm{mM}$ potassium persulfate 를 1:1 비율로 혼합하고, 실온인 암소에서 24시간 동안 방치 하여 $\mathrm{ABTS}^{+}$을 형성시킨 후 $732 \mathrm{~nm}$ 에서 흡광도 값이 $0.700 \pm$ 0.030 이 되도록 phosphate buffer saline(PBS, $\mathrm{pH}$ 7.4)으로 희 석하였다. 시료 $50 \mu \mathrm{L}$ 에 $\mathrm{ABTS}$ 용액 $950 \mu \mathrm{L}$ 를 혼합하였고, control은 시료 대신 증류수를 이용하였다. 혼합액을 실온, 암 소에서 10 분간 유지한 후 $732 \mathrm{~nm}$ 에서 측정한 뒤 계산식에 의해 활성을 산출하였다.

ABTS radical scavenging ability (\%)

$$
=100-\{(\mathrm{OD} \text { of sample } / \mathrm{OD} \text { of control }) \times 100\}
$$

\section{총폴리페놀 함량 측정}

총 폴리페놀 함량은 Singleton과 Ross(1965)의 Folin-Denis 법을 응용하여 비색 정량하였다. 일정하게 희석한 시료 0.2 $\mathrm{mL}$ 에 증류수 $1.8 \mathrm{~mL}$ 를 첨가하여 $2 \mathrm{~N}$ Folin-Ciocalteu's phenol reagent(Sigma-Aldrich Co.) $0.2 \mathrm{~mL}$ 를 혼합하여 6분 간 반응한 후, $7 \% \mathrm{Na}_{2} \mathrm{CO}_{3} 2 \mathrm{~mL}$ 를 첨가하여 암소에서 2시간 반응시켰다. 반응물은 $750 \mathrm{~nm}$ 에서 흡광도를 측정하였고, gallic acid(Sigma-Aldrich Co.)를 이용한 표준곡선으로 양을 환산하여 $\mathrm{mg}(\mathrm{GAE}) / 100 \mathrm{~mL}$ 로 나타내었다.

\section{통계처리}

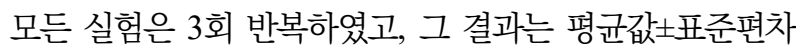
로 나타내었다. 각 실험구 간의 유의성 $(\mathrm{p}<0.05)$ 검증을 위해 통계적 분석은 $\mathrm{SAS}($ Statistical Analysis System program, SAS Institute., Cary, NC, USA)와 XLSTAT(Microsoft Corp., Redmond, WA, USA) 프로그램을 이용하여 분산분석 (analysis of variance, ANOVA)한 후 Duncan's multiple range test로 검증하였다.

\section{결과 및 고찰}

\section{고문헌 재현한 '전자손초'의 품질 특성}

고문헌에 기록된 방법으로 재현한 ‘전자손초’(대추식초)의 
산도와 $\mathrm{pH}$ 변화는 Fig. $2 \mathrm{~A}$ 와 같다. 산도는 $0.71-1.67 \%$ 이며, $\mathrm{pH}$ 는 3.03-3.36\%였다. 산도는 발효 14 일차에 7일차보다 약 2 배 증가하였고, 21 일차에 $1.67 \%$ 였다. $\mathrm{pH}$ 변화는 14 일차까 지 다소 감소하다 21 일까지는 유지되는 경향을 보였다. '전 자손초’의 유기산을 분석한 결과는 Fig. 2B와 같다. 자연발효 에 의해 acetic acid는 7일차 $(250.48 \mathrm{mg} / 100 \mathrm{~mL})$ 부터 21일차 $(413.13 \mathrm{mg} / 100 \mathrm{~mL}$ )까지 꾸준히 증가하였다. Lactic acid는 14 일차 $(304.68 \mathrm{mg} / 100 \mathrm{~mL})$ 까지 증가하다가 21일차 $(264.61$ $\mathrm{mg} / 100 \mathrm{~mL}$ )에는 소폭 감소하였고, malic acid는 21일차까지 꾸준히 증가하는 모습을 보였다. 대추의 주요 유기산은 malic, citric, succin, tartaric acid 등으로 알려져 있으며(Gao 등, 2012; Wang 등, 2018), 재현한 '전자손초'의 경우도 원료 에 의해 malic acid가 꾸준히 증가되는 것으로 생각된다. Jeong 등(1998a)은 전통적인 병행복발효방법은 산도와 수율 이 낮을뿐만 아니라, 초산 이외 젖산이 많이 함유되어 있다고 하였는데, 본 연구와 결과와 유사하였다. 재현한 '전자손초' 의 주요 유기산은 acetic acid와 lactic acid 였으며, 발효 21일 차에 산도 $1.67 \%, \mathrm{pH} 3.05$ 로 식초의 식품공전 기준인 acetic

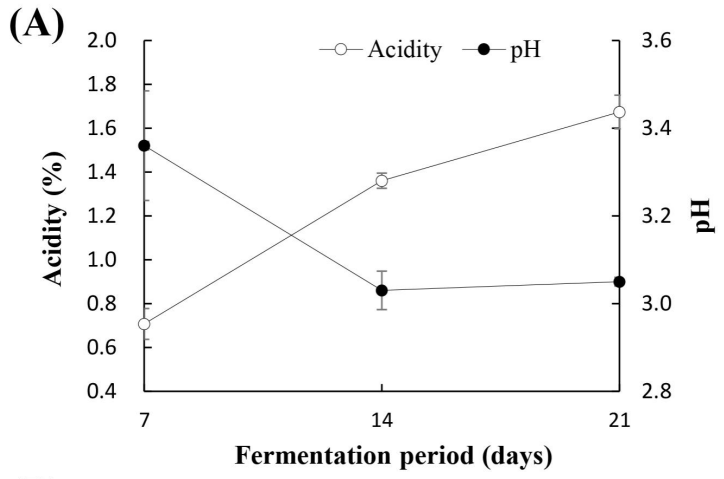

(B)

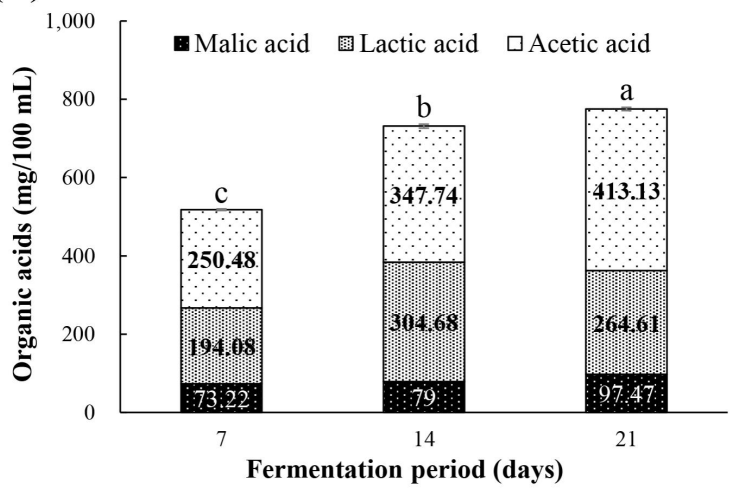

Fig. 2. (A) Changes in $\mathrm{pH}$ and acidity during the fermentation period of 'Jeonjashoncho', (B) The organic acid content according to fermentation period of 'Jeonjashoncho'.

Values represent the mean \pm SD $(n=3)$. Means with different letters above a bar are significantly different at $\mathrm{p}<0.05$. aicd $4 \%$ 에 도달하지는 못했다.

\section{발효조건별 $\mathrm{pH}$ 변화}

Beak 등(2014)은 재래 식초에서 초산균을 분리하고 균의 최적 생장 $\mathrm{pH}$ 는 5.0-6.5이며, 보다 낮은 $\mathrm{pH} 3.5$ 에서도 생육하 는 균주를 발견하여 균주의 특성이 다양하다고 하였다. 이에 최적 발효 $\mathrm{pH}$ 를 선정하고자 발효주의 초기 $\mathrm{pH}$ 를 $3,4,5$ 로 조절하여 초산발효를 실시하였다. 대추 식초의 발효기간 및 온도에 따른 $\mathrm{pH}$ 변화를 조사하여 Fig. 3에 나타내었다. 초산
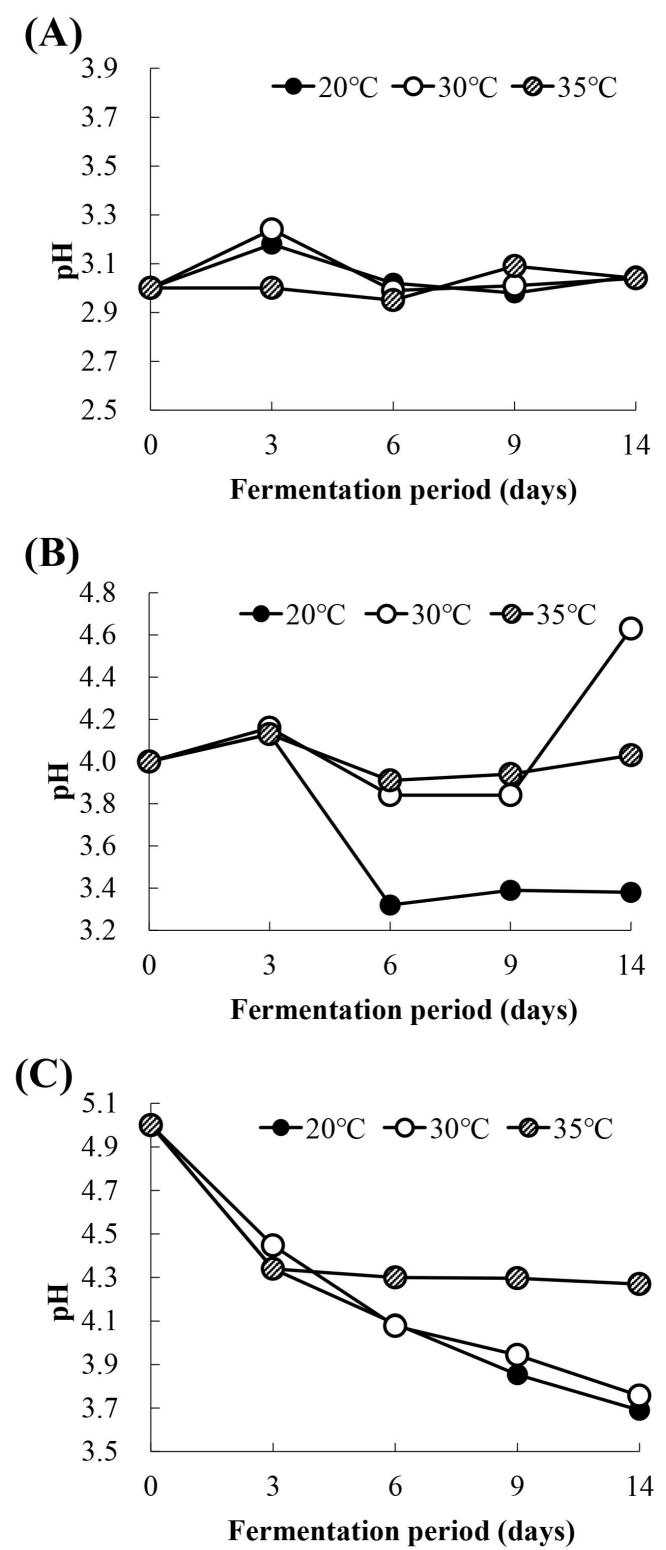

Fig. 3. Changes in pH during the fermentation period of jujube vinegar.

A, pH 3; B, pH 4; C, pH 5. 
발효에서 총산 함량이 높아지면 $\mathrm{pH}$ 가 낮아지는 음의 상관관 계를 나타내며, $\mathrm{pH}$ 감소로 인해 잡균의 증식 억제와 함께 산 생성이 증가한다고 보고하였다(Jo 등, 2015; Na 등, 2013). 본 연구에서도 발효가 진행됨에 따라 산도가 증가함에 따라 $\mathrm{pH}$ 는 감소하는 경향을 보였다. 초기 $\mathrm{pH}$ 3의 경우 모든 온도 조건에서 $\mathrm{pH}$ 3.0-3.2로 $\mathrm{pH} 4, \mathrm{pH} 5$ 처리구에 비해 변화가 거의 없었다. $\mathrm{pH} 4,20^{\circ} \mathrm{C}, 6$ 일에 $\mathrm{pH}$ 가 3.3 으로 감소한 뒤 발 효가 종료될 때까지 $\mathrm{pH}$ 3.4로 유지되었다. $\mathrm{pH}$ 5에서는 발효 기간이 경과됨에 따라 $\mathrm{pH}$ 가 감소하였는데, $20,30^{\circ} \mathrm{C}$ 처리구 에서 발효 3 일차 이후로 $\mathrm{pH}$ 가 지속적으로 감소하였다.

\section{발효조건별 총산도, 알코올 함량}

초기 $\mathrm{pH}$ 및 온도별 알코올, 산도 변화는 Fig. 4에 나타냈 다. 식초는 초산균에 의해 알코올을 영양원으로 이용하여 분 해시키는데, 아세트알데히드를 거쳐 아세트산과 $\mathrm{CO}_{2}$ 를 형성 한다(Eom 등, 2019). 즉, 초산균은 알코올을 소비하며 발효
가 진행되고, 알코올 소비량과 초산 생성 그래프는 반비례 그 래프 형태를 그린다. 이에 알코올 농도가 $0 \%$ 가 될 때 초산발 효 종료 시점으로 판단하였다. 초기 $\mathrm{pH} 3$ 일 때, 초기 산도는 $3.3 \%$ 로 나타났으나, 발효가 진행될수록 $20^{\circ} \mathrm{C}$ 처리를 제외하 고는 산도가 크게 오르지 않았다. 초기 $\mathrm{pH} 4$ 경우, $20^{\circ} \mathrm{C}$ 에서 이상적으로 산도가 증가하였는데, 발효 14 일에 산도가 $10.4 \%$ 까지 증가하였다. 초기 $\mathrm{pH} 5$ 경우도 21 일에 $20,30^{\circ} \mathrm{C}$ 에서 각 각 $5.1 \%, 5.7 \%$ 로 증가하였다. Jeong 등(1998b)은 식초의 제 조에서 초산균의 작용으로 생성되는 초산은 총산 함량을 좌 우하는 품질 판정의 지표가 된다고 하였으며, 초산발효에 있 어 온도가 낮으면 균주 성장이 억제되고, 높으면 오염의 위험 과 더불어 초산 생성능이 떨어져 적절한 온도조절이 필요하 다(Kim 등 1997). Park 등(2002)은 양조식초에서 분리한 고산 도 초산균의 생육을 관찰한 결과, $15-34^{\circ} \mathrm{C}$ 까지 생육 가능하였 으며, $30^{\circ} \mathrm{C}$ 에서 가장 생육이 양호하였다고 보고한 바 있다(Jo 등, 2015; Kim 등, 2008). 반면, Lee 등(1999)은 감식초에서
pH $3,2^{\circ} \mathrm{C}$

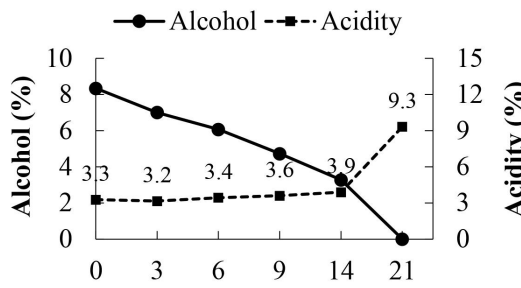

Fermentation period (days)

pH $4,20^{\circ} \mathrm{C}$

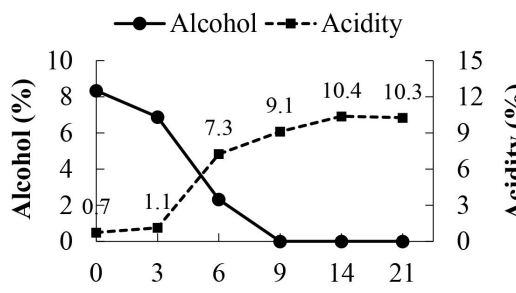

Fermentation period (days)

pH $5,20^{\circ} \mathrm{C}$

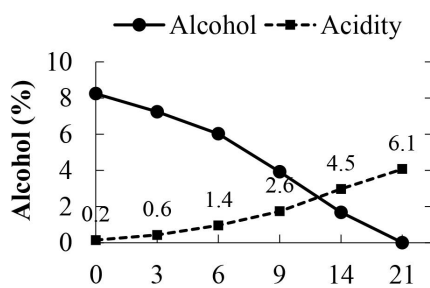

Fermentation period (days)
pH 3, $30^{\circ} \mathrm{C}$

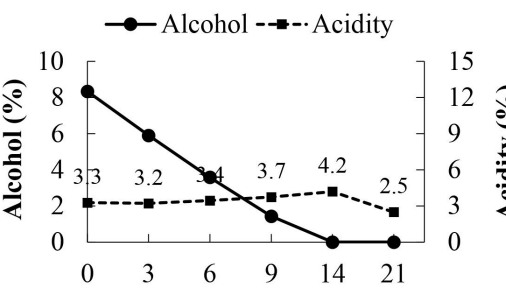

Fermentation period (days)

pH 4, 30 ${ }^{\circ} \mathrm{C}$

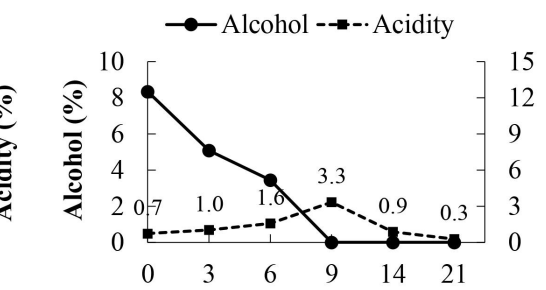

Fermentation period (days)

pH $5,30^{\circ} \mathrm{C}$
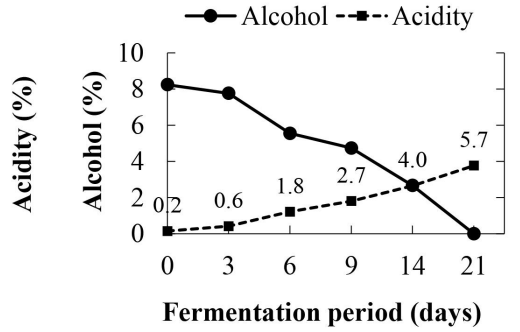

pH 3, $3^{\circ} \mathrm{C}$

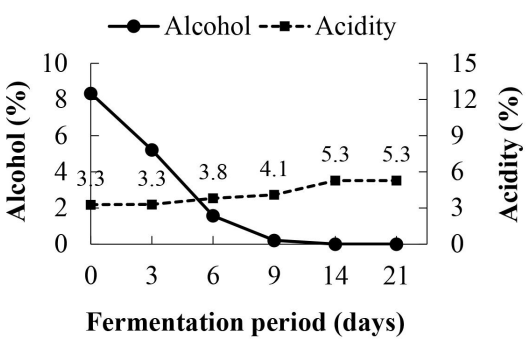

pH $4,3^{\circ} \mathrm{C}$

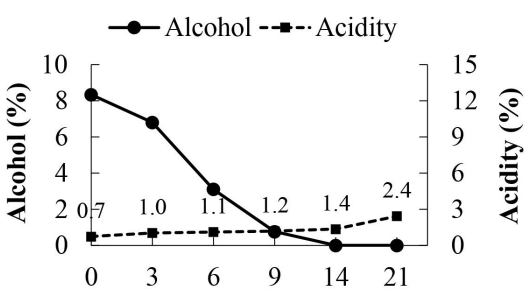

Fermentation period (days)

pH 5, $35^{\circ} \mathrm{C}$

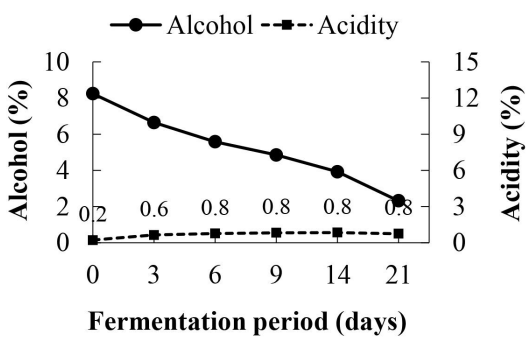

Fig. 4. Changes in acidity during the fermentation period of jujube vinegar. 
분리 · 동정한 Acetobacter sp.를 이용하여 제조한 알로에 식 초는 $25^{\circ} \mathrm{C}$ 에서 가장 높은 산생성량을 보였으며, $30^{\circ} \mathrm{C}$ 에서는 산도가 급격하게 감소하는 경향을 보였다. Lee 등(2019)의 연구에서 초산발효를 위해 초기 $\mathrm{pH}$ 를 조절함에 따라 산 생성 능이 차이가 나는데, A. pasterianus $\mathrm{A} 37, \mathrm{~B} 7$ 은 $\mathrm{pH} 4,20^{\circ} \mathrm{C}$ 조건에서 산 생성능이 가장 우수하였다. 이는 본 연구에서 사 용한 A. oryzifermentans(KACC 19301)의 발효 특성과 유사 하였다. 결과적으로 초기 $\mathrm{pH} 4,20^{\circ} \mathrm{C}$ 조건에서 발효기간이 경과됨에 따라 $\mathrm{pH}$, 알코올 함량은 낮아지고, 총산 함량이 발 효 14 일차에 $10.4 \%$ 로 가장 높았다.

\section{발효조건별 유기산 함량}

대추식초의 초기 $\mathrm{pH}$ 및 발효온도에 따른 발효기간별 유기 산 분석 결과는 Fig. 5 와 같다. 초기 $\mathrm{pH}$ 3에서는 온도와 관계 없이 주요 유기산은 citric acid이며, 이는 원료 성분 또는 $\mathrm{pH}$ 조절을 위해 첨가한 구연산에 영향을 받은 것으로 보여진다. Acetic acid는 식초의 초산발효 중에 초산균이 알코올을 발효 기질로 하여 생성되며(Baek 등, 2014), 식초의 발효 공정 관 리 및 품질에 있어 중요한 지표이다(Moon 등, 1997). pH 4, $20^{\circ} \mathrm{C}$ 에서는 발효 6 일부터 acetic acid가 점차 증가하였다. 특 히, 발효 14 일에서 총 유기산 함량이 $6,568 \mathrm{mg} / 100 \mathrm{~mL}$ 로 이 중 acetic acid가 약 $83 \%(5,475 \mathrm{mg} / 100 \mathrm{~mL})$ 로 높게 나타나면 서 초산발효가 원활하게 이뤄졌음을 알 수 있었다. 그 밖에
$\mathrm{pH} 4$ 에서 $30,35^{\circ} \mathrm{C}$ 처리에서는 초산발효의 뚜렷한 특징을 확 인할 수 없었다. $\mathrm{pH} 5$ 에서도 $20^{\circ} \mathrm{C}$ 에서 발효 14 일차에 acetic $\operatorname{acid}(3,855 \mathrm{mg} / 100 \mathrm{~mL})$ 함량이 급격하게 증가하는 것을 볼 수 있는데, $\mathrm{pH}$ 를 확인해보면(Fig. $3 \mathrm{C}$ ) 발효 6일 차에 $\mathrm{pH}$ 4로 떨어진 후 꾸준히 acetic acid가 증가하였다. 결과적으로 Acetobacter oryzifermentans(KACC19301)를 이용하여 초산 발효 시 $20^{\circ} \mathrm{C}, \mathrm{pH}$ 4에서 초산발효가 가장 원활한 것을 확인 할 수 있었다.

\section{전자혀를 이용한 대추식초의 맛성분 분석}

가장 산 생성능이 우수했던 초기 $\mathrm{pH} 4,20^{\circ} \mathrm{C}$ 에서 제조된 식초의 맛성분 변화를 전자혀를 이용하여 확인한 결과는 Fig. 6 과 같다. 식초의 가장 중요한 맛인 신맛(AHS)은 발효 기간 이 지남에 따라 증가하였다. 앞선 실험들에서 산도 및 유기산 함량이 증가하는 것과 같은 경향이었다. 척도가 2 이상 차이 나면 사람이 구분할 수 있을 정도의 유의적인 차이라고 볼 수 있다는 제조사의 기준에 따라(Hayashi 등, 2008; Jo 등, 2012), 0 일 차와 6 일 차는 척도 값이 4 정도 차이가 나 발효 기간이 지남에 따라 신맛을 느낄 수 있는 정도가 증가됨을 알 수 있었다. 감칠맛(NMS) 역시 신맛과 비슷하게 척도 값이 4 차이를 보였다. 짠맛(CTS)도 감칠맛과 신맛과 같이 발효가 진행될수록 감소하였고, 반대로 발효 기간이 경과 됨에 따라 쓴맛(ANS), 단맛(PKS)이 감소하는 것을 볼 수 있었다. 단순

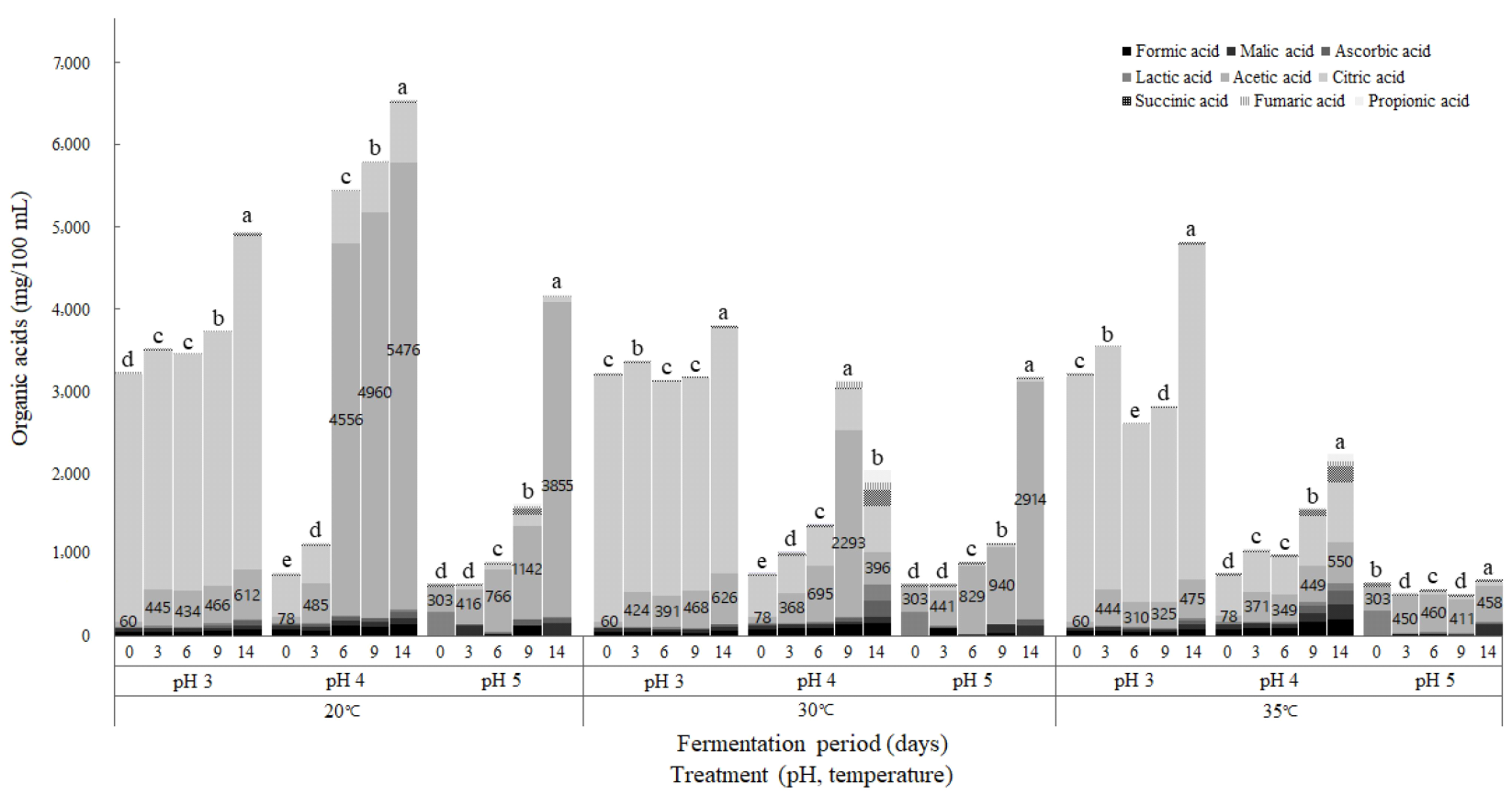

Fig. 5. The organic acid content according to fermentation period of jujube vinegar at initial $\mathrm{pH}(3,4,5)$ and temperature $\left(20,30,35^{\circ} \mathrm{C}\right)$. Values represent the mean \pm SD $(n=3)$. Means with different letters above a bar are significantly different at $p<0.05$. 
(A)

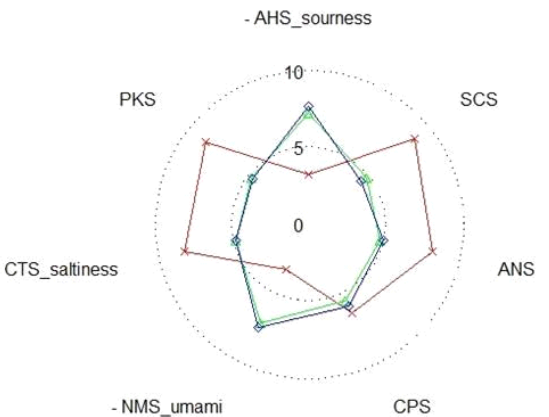

(B)

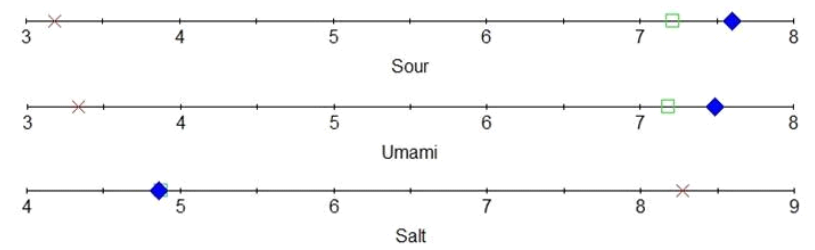

Fig. 6. Taste profile patterns of jujube vinegar.

Fermentation period: $\times, 0 ; \square, 6 ; \diamond, 14$.

$\mathrm{A}$, changes in organoleptic characteristics of jujube vinegar by electronic tongue; $\mathrm{B}$, changes of intensity scale in organoleptic characteristics of jujube vinegar by electronic tongue.

히 발효가 진행되는 동안 산도만 증가하는 것이 아니라, 소비 자가 섭취하였을 때 그 강도가 확실하게 나타날 수 있는 정도 의 맛 차이를 보이며 신맛과 감칠맛이 증가하는 것을 확인할 수 있었다.

\section{시판 식초 2종의 제조과정 및 품질 특성}

실험에 사용한 시판식초의 제조과정과 품질 특성은 Table 1 과 같다. A 식초는 원료의 10 배 가수하여 알코올, 초산 발효 의 과정을 거치는 제조 공정과 발효 후 잔당이 약 $8{ }^{\circ} \mathrm{Brix}$ 인 점이 본 실험과 유사하였다. 차이점으로는 대추 발효식초는 대추농축액에 효모(Saccharomyces cerevisiae YM22)를 접종 하여 알코올 발효한 뒤 초산균(Acetobacter oryzifermentans
(KACC19301))을 접종하여 초산발효 하였고, A 식초는 유기 현미, 엿기름 등 부재료를 첨가한 것으로 보아 누룩을 이용하 여 알코올 발효를 하고 자연발효를 통한 숙성과정이 있는 차 이점이 있었다. B 식초는 원료 $100 \%$ 를 농축하여 $10{ }^{\circ} \mathrm{Brix}$ 의 농축액을 $30 \%$ 사용하고, 알코올 발효과정이 본 제조과정에 따로 명시되지 않아 병행복발효인지, 알콜 발효 후 초산 발효 를 진행한 것인지 명확히 알 순 없었지만 초산발효 후 블랜딩 하여 숙성하는 과정이 차이가 있었다. 그리고 B 식초는 음료 용 식초로 판매되고 있어 당이 추가로 첨가되어 $42.7^{\circ} \mathrm{Brix}$ 로 매우 높았다.

\section{ABTS radical 소거능}

$\mathrm{ABTS}$ 는 유리기들과 반응하여 안정한 $\mathrm{ABTS}$ 형태의 양이 온 라디칼을 형성하므로(Lee 등, 2008) 대부분 ABTS는 친수 성 물질과 소수성 물질의 항산화력 측정이 가능하다.

초기 $\mathrm{pH} 4,20^{\circ} \mathrm{C}$ 에서 제조된 식초(이하 $\mathrm{AO}$ 식초)와 시판 되고 있는 대추식초(2종)의 ABTS radical 소거능을 비교하였 고, 측정한 결과는 Table 2 와 같다. $\mathrm{AO}$ 식초의 경우, 제조 공 정과 제조 후 식초 품질이 가장 비슷했던 식초 $\mathrm{A}$ 에 비하여 ABTS radical 소거능이 약 1.5 배 높았으며, 이는 식초 제조에 사용한 원료 함량의 차이인 것으로 생각된다. 식초 $\mathrm{B}$ 의 경우 는 원료 함량이 $30 \%$ 임에도 불구하고 ABTS radical 소거능

Table 2. ABTS radical scavenging activities and total phenolics content in the jujube vinegars

\begin{tabular}{ccc}
\hline $\begin{array}{c}\text { Vinegar } \\
\text { type }\end{array}$ & ABTS (\%) & $\begin{array}{c}\text { Total phenolics } \\
(\mathrm{mg}(\mathrm{GAE}) / 100 \mathrm{~mL})\end{array}$ \\
\hline $\mathrm{AO}^{1)}$ & $90.588 \pm 0.778^{\mathrm{b} 2)}$ & $1,131.3 \pm 0.1^{\mathrm{a}}$ \\
$\mathrm{A}$ & $60.441 \pm 0.964^{\mathrm{c}}$ & $686.167 \pm 0.1^{\mathrm{c}}$ \\
$\mathrm{B}$ & $93.382 \pm 0.147^{\mathrm{a}}$ & $936.011 \pm 0.1^{\mathrm{b}}$ \\
\hline
\end{tabular}

${ }^{1)} \mathrm{AO}$, jujube vinegar; $\mathrm{A} \& \mathrm{~B}$, commercial jujube vinegar.

${ }^{2)}$ Values represent the mean $\pm S D(n=3)$. Means with different letters are significantly different at $\mathrm{p}<0.05$.

Table 1. Commercial vinegar-manufacturing process and quality characteristics

\begin{tabular}{|c|c|c|c|c|}
\hline $\begin{array}{l}\text { Vinegar } \\
\text { type }\end{array}$ & Manufacturing process & $\begin{array}{l}\text { Raw material } \\
\text { content }(\%)\end{array}$ & $\begin{array}{l}\text { Acidity } \\
(\%)\end{array}$ & $\begin{array}{l}\text { Soluble solids } \\
\text { ('brix \%) }\end{array}$ \\
\hline $\mathrm{AO}^{1)}$ & $\begin{array}{l}\text { Raw material } \rightarrow \text { Alcohol fermentation } \\
\quad \rightarrow \text { Acetic acid fermentation }\end{array}$ & 100 & $10.27 \pm 0.08$ & $8.3 \pm 0.0$ \\
\hline A & $\begin{array}{l}\text { Raw material } \rightarrow \text { Alcohol fermentation } \\
\rightarrow \text { Acetic acid fermentation } \rightarrow \text { Aged until } 4 \% \text { acetic acid }\end{array}$ & 83 & $3.72 \pm 0.06$ & $8.9 \pm 0.1$ \\
\hline $\mathrm{B}$ & $\begin{aligned} & \text { Raw material } \rightarrow \text { Acetic acid fermentation } \\
& \rightarrow \text { Pasteurization, Filtration } \rightarrow \text { Blending } \rightarrow \text { Aging }\end{aligned}$ & 30 & $1.14 \pm 0.04$ & $42.7 \pm 0.0$ \\
\hline
\end{tabular}

${ }^{1)} \mathrm{AO}$, jujube vinegar; $\mathrm{A} \& \mathrm{~B}$, commercial jujube vinegar. 
이 $93 \%$ 로 높았는데, 이는 블렌딩 과정에서 첨가된 사과농축 액, 구연산 및 비타민 $\mathrm{C}$ 에 의한 것으로 판단된다.

\section{총 폴리페놀 함량}

항산화 물질에 관련한 연구는 다양한 분야에서 진행되고 있으며, 성인병 예방효과가 증명된 항산화 물질인 비타민 A, $\mathrm{C}, \mathrm{E}$ 와 같은 항산화 비타민과 페놀산, 플라보노이드 등의 식물 성 폴리페놀 화합물과 같은 천연 항산화제에 대한 연구가 체계 적으로 진행되고 있다(Kim과 Kim 1999a; Kim 등 1999b). 그 중 채소나 과일에서 폴리페놀은 강한 결합 상태로 존재하여 흡수되기 쉽지 않은데 비해 알코올에서는 수용성 상태로 바 뀌어 생물학적으로 이용성이 증진되는 강점이 있다(Alonso 등, 2004). 또한 폴리페놀 물질은 2 차 대사산물로써 이들이 가진 phenolic hydroxyl기로 단백질 및 기타 거대 분자들과 결합한다. 이에 항산화 효과와 생리활성 기능을 가진다는 보 고가 있다(Fine, 2000). 따라서 알코올을 이용하여 2단 발효 를 진행하였던 대추식초의 폴리페놀 함량을 분석하였고, 그 결과는 다음과 같다(Table 2). 총 페놀 함량은 식초 $\mathrm{A}$ 에서 $686.167 \mathrm{mg}(\mathrm{GAE}) / 100 \mathrm{~mL}$ 대비 $\mathrm{AO}$ 식초에서 $1,131.333$ $\mathrm{mg}(\mathrm{GAE}) / 100 \mathrm{~mL}$ 로 더 높은 함량을 보였다. 건대추 열수추 출물을 이용한 대추와인 연구에 따르면 대추 추출물의 총 폴 리페놀 함량은 $1.81 \mathrm{mg} / \mathrm{mL}$ 이며, 대추 와인 발효가 진행됨에 따라 발효 9일째 $3.77 \mathrm{mg} / \mathrm{mL}$ 로 유의적으로 증가하는 것으로 보고하고 있다(Eom 등, 2016). 발효가 일어나지 않은 상태의 대추 총 폴리페놀과 비교했을 때, 알코올 발효 및 초산발효를 거치면서 폴리페놀 함량이 늘어나는 것으로 판단된다.

\section{요 약}

조선시대 고문헌 『산가요록』에 기록된 대추를 이용한 식 초인 '전자손초'를 재현한 후 품질 특성을 확인하였다. 재현 한 '전자손초'의 산도는 $1.67 \%, \mathrm{pH} 3.05$ 이며, 주요 유기산은 acetic acid와 lactic acid였으며, 식초의 식품공전 기준인 acetic acid 4\%에 도달하지는 못했다. 이에 따라 효모 (Saccharomyces cerevisiae YM22)와 초산균(Acetobacter oryzifermentans(KACC19301))을 접종하여 2단계 발효 과정 으로 현대적 공정개선을 통해 대추식초를 제조하였다. 발효 최적 조건 선정을 위해 초기 $\mathrm{pH}$ 를 $3,4,5$ 로 조절하여 20 , $30,35^{\circ} \mathrm{C}$ 에서 발효한 후 $\mathrm{pH}$, 총산도, 유기산을 분석하였다. $\mathrm{pH} 4,20^{\circ} \mathrm{C}$ 에서 발효 기간이 지남에 따라 $\mathrm{pH}$ 와 알코올 함량 은 감소하였고, 총산도는 $10.4 \%$ 로 증가하였다. 유기산 함량 의 경우 발효 0 일차에 비해 약 9 배 증가하였으며, acetic acid 의 경우 $78.11 \mathrm{mg} / 100 \mathrm{~mL}$ 에서 14 일차에 $5,475.61 \mathrm{mg} / 100$ $\mathrm{mL}$ 로 증가하여 acetic acid 생성이 가장 우수하였다. 전자혀
를 이용하여 맛성분 변화를 비교한 결과, 신맛과 감칠맛이 증 가하는 것을 확인할 수 있었다. 최적 발효조건인 $\mathrm{pH} 4,20^{\circ} \mathrm{C}$ 에서 제조한 대추식초와 시판식초 2 종의 기능성을 분석한 결 과, 시판식초 2종에 비해 $\mathrm{ABTS}$ 라디칼 소거능 $(90.588 \%)$ 과 총폴리페놀 함량 $(1,131.333 \mathrm{mg}(\mathrm{GAE}) / 100 \mathrm{~mL})$ 모두 높았다. 고문헌에 기록된 '전자손초'(대추식초)를 재현하고, 종균을 이용한 2단계 발효과정으로 공정을 개선하고, 대추 발효식초 의 최적 발효조건으로 초기 $\mathrm{pH} 4,20^{\circ} \mathrm{C}$ 를 선정하였다. 이러 한 연구결과를 바탕으로 농산업체의 식초 산업의 발전과 소 득 증진에 기여하고자 한다.

\section{감사의 글}

이 논문은 농촌진흥청 농업과학기술개발사업(PJ013418) 의 지원으로 이루어졌으며, 연구비 지원에 감사드립니다.

\section{Conflict of interests}

The authors declare no potential conflict of interest.

\section{ORCID}

Hyeon-Ju Park https://orcid.org/0000-0002-9739-9868

Hee-Min Gwon https://orcid.org/0000-0002-8808-5875

\section{References}

Alonso AM, Castro R, Rodriguez MC, Guillen DA, Barroso CG. Study of the antioxidant power of brandies and vinegars derived from Sherry wines and correlation with their content in polyphenols. Food Res Int, 37, 715-721 (2004)

Baek SY, Park HY, Lee CH, Yeo SH. Comparison of the fermented property and isolation of acetic acid bacteria from traditional Korean vinegar. Korean J Food Preserv, 21, 903-907 (2014)

Blois MS. Antioxidant determinations by the use of a stable free radical. Nature, 181, 1199-1200 (1958)

Cho HD, Kim JH, Lee JH, Hong SM, Yee ST, Seo KI. Anti-fatigue effect of a cucumber vinegar beverage on rats after high-intensity exercise. Korean J Food Sci Technol, 49, 209-214 (2017)

Choi KS. Changes in physiological and chemical characteristics of jujube fruits (Zizyphus jujuba Miller) var. 
Bokjo during maturity and postharvest ripening. J Resour Develop, 9, 47-53 (1990)

Eom HJ, Yoon HS, Kwon NR, Jeong YJ, Kim YH, Hong ST, Han NS. Comparison of the quality properties and identification of acetic acid bacteria for aronia vinegar. J Korean Soc Food Sci Nutr, 48, 1397-1404 (2019)

Eom IJ, Choi JI, Kim IH, Kim TH, Kim SH. Changes in the physicochemical and antioxidant characteristics during the fermentation of jujube wine using hot water extract of dried jujube. J Life Sci, 26, 1298-1307 (2016)

Fine AM. Oligomeric proanthocyanidin complexes: History, structure, and phytopharmaceutical applications. Altern Med Rev, 5, 114-151 (2000)

Gao QH, Wu CS, Yu JG, Wang M, Ma YJ, Li CL. Textural characteristic, antioxidant activity, sugar, orgarnic acid, and phenolic profiles of 10 promising jujube (Ziziphus jujuba Mill.) selections. J Food Sci, 77, 1218-1225 (2012)

Hayashi N, Chen R, Ikezaki H, Ujihara T. Evaluation of the umami taste intensity of green tea by a taste sensor. $\mathrm{J}$ Agric Food Chem, 56, 7384-7387 (2008)

Hong CE, Chun YH, Lyu SY. Anti-inflammatory and antioxidant effects of Zizyphus jujuba Miller var. inermis extracts. Kor J Pharmacogn, 50, 86-95 (2019)

Hong JY, Nam HS, Shin SR. Changes on the antioxidant activities of extracts from the Ziziphus jujube Miller fruits during maturation. Korean J Food Preserv, 17, 712-719 (2010)

Jeong YJ, Lee GD, Kim KS. Optimization for the fermentation condition of persimmon vinegar using response surface methodology. Korean J Food Sci Technol, 30, 203-1208 (1998a)

Jeong YJ, Seo JH, Jung SH, Shin SR, Kim KS. The quality comparison of uncleaned rice vinegar by two stages fermentation with commercial uncleaned rice vinegar. Korean J Postharvest Sci Technol, 5, 374-379 (1998b)

Jeong YJ, Lee MH. A view and prospect of vinegar industry. Food Ind Nutr, 5, 7-12 (2000)

Jo HS, Kim KH, Kim MJ, Kim HJ, Im YJ, Kwon DH, Heu MS, Kim JS. Sensory characterization of domestic mottled skate Raja pulchra as affected by area caught, sex and fish weight. Kor J Fish Aquat Sci, 45, 619-626 (2012)

Jo YJ, Han JW, Min DL, Lee YE, Choi YJ, Lim SW.
Optimization of acetic acid fermentation for producing vinegar from extract of jujube (Zizyphus jujuba Mill.) fruits. Korean J Food Sci Technol, 47, 711-718 (2015)

Kang SI, Yoon IS, Choi KS, Kim JS, Lee JS, Heu MS, Kim JS. Sensory and nutritional characteristics of seasoned broughton's ribbed Ark Scapharca broughtonii product. Korean J Fish Aquat Sci, 53, 342-350 (2020)

Kim H, Nam HS, Choi CS, Kim DW. Research trends of vinegar using medicinal herb. J Appl Orient Med, 13, 31-36 (2013)

Kim IH, Jeong CH, Park SJ, Shim KH. Nutritional components and antioxidative activities of jujube (Zizyphus jujuba) fruit and leaf. Korean J Food Preserv, 18, 341-348 (2011)

Kim JS, Jung HY, Park EY, Noh BS. Flavor analysis of commercial Korean distilled spirits using an electronic nose and electronic tongue. Korean J Food Sci Technol, 48, 117-121 (2016)

Kim NE, Kim WK. Effect of antioxidant vitamins supplementation of antioxidative status and plasma lipid profiles in Korea NIDDM patient. Korean J Nutr, 32, 775-780 (1999a)

Kim SW, Park JH, Jun HK. Analysis of optimum condition for production of an onionic vinegar by two-step fermentations. J Life Sci, 18, 1410-1414 (2008)

Kim SY, Kim MK, Jang KS, Kim SD. Effect on taste correction of jujube water extract concentrate. J East Asian Soc Diet Life, 4, 87-94 (1994)

Kim WK, Kim HY, Kim MJ, Kim SH. Effects of vitamine E supplementation on antioxidant status and immune response in female athletes. Korean J Nutr, 32, 781-786 (1999b)

Kim YT, Seo KI, Jung YJ, Lee YS, Shim KH. The production of vinegar using citron (Citus junos Seib.) juice. J East Asian Soc Diet Life, 7, 301-307 (1997)

Kwon SH, Jeong EJ, Lee GD, Jeong YJ. Preparation method of fruit vinegars by two stage fermentation and beverage including vinegar. Food Ind Nutr, 5, 18-24 (2000)

Kwon YI, Jung IC, Kim SH, Kim SY, Lee JS, Lee JS. Changes in properties of pitted jujube during drying and extraction. J Korean Soc Appl Biol Chem, 40, 43-47 (1997)

Lee DS, Ryu IH, Lee KS, Shin YS, Chun SH. Optimization in the preparation of aloe vinegar by Acetobacter sp. and 
inhibitory effect againse lipase activity. J Korean Soc Appl Biol Chem, 42, 105-110 (1999)

Lee SJ, Kim SH, Kim SY, Yeo SH. Quality characteristics of Kujippong (Cudrania tricuspidata) vinegar fermented by various acetic acid bacteria. Korean J Food Preserv, 26, 766-776 (2019)

Lee SO, Kim MJ, Kim DG, Choi HJ. Antioxidative activities of temperature-stepwise water extracts from Inonotus obliquus. J Korean Soc Food Sci Nutr, 34, 139-147 (2005)

Lim EJ, Cha GH. Study on manufacturing of vinegar through literatures of the Joseon Dynasty. Korean J Soc Food Cult, 25, 680-707 (2010)

Moon SY, Chung HC, Yoon HN. Comparative analysis of commercial vinegars in physicochemical properties, minor components and organoleptic tastes. Korean J Food Sci Technol, 29, 663-670 (1997)

Na HS, Choi GC, Yang SI, Lee JH, Cho JY, Ma SJ, Kim JY. Comparison of characteristics in commercial fermented vinegars made with different ingredients. Korean J Food Preserv, 20, 482-487 (2013)

Park JH, Chung JE, Kang HJ, Oh HK, Lee KH, Kim YH, Yoon GM, Eom HJ. Nutritional compositions and physiochemical properties of domestic jujube (Zizyphus jujube Miller) varieties. Korean J Food Nutr, 30, 841-
846 (2017)

Park MH, Lyu DK, Ryu CH. Characteristics of high acidity producing acetic acid bacteria isolated from industrial vinegar fermentation. J Korean Soc Food Sci Nutr, 31, 394-398 (2002)

Rual Development Administration. Translated Version of the Sangayorok by Jeon Sun-Eui. Minhooart, Seoul, Korea, p 97 (2004)

Rual Development Administration. Traditional Wine Manufacturing Method of Ancient Literature. Human Culture Arirang, Seoul, Korea, p 10 (2016)

Singleton VL, Rossi JA. Colorimetry of total phenolics with phosphomolybdic-phosphotungstic acid reagents. Am J Enol Vitic, 16, 144-158 (1965)

Wang L, Fu H, Wang W, Wang Y, Zheng F, Ni H, Chen F. Analysis of reducing sugars, organic acids and minerals in 15 cultivars of jujube (Ziziphus jujuba Mill.) fruits in China. J Food Compos Anal, 73, 10-16 (2018)

Won YS, Min HJ, Seo KI. The current status, functionalities, and developmental strategies of the vinegar industry. Food Sci Ind, 53, 215-224 (2020)

$\mathrm{Yu}$ MH, Im HG, Lee HJ, Ji YJ, Lee IS. Components and their antioxidantive activities of methanol extracts from sarcocarp and seed of Zizyphus jujuba var. inermis Rehder. Korean J Food Sci Technol, 38, 128-134 (2006) 